\title{
Revolution in the Stacks: A Bibliography of Selected Multimedia Anarchist Resources in English
}

\author{
Kevin Stranack, Simon Fraser University Library, Burnaby, Canada
}

\begin{abstract}
Provides a selective bibliography of English language multimedia resources for librarians, teachers, students, and activists interested in anarchism. Includes lists of suggested books, encyclopedias, journals, music, Web sites, e-books, videos, and indexes, as well as selection tools to assist librarians in developing anarchist collections.
\end{abstract}

The current issue and full text archive of this journal is available at: http://www.emeraldinsight.com/0160-4953.htm

\section{Introduction}

In 1999, protests against the World Trade Organization and the "Battle in Seattle" put the word "anarchy" back into the popular political vocabulary. Since then, international demonstrations against war and neoliberalism have often involved groups of explicitly antiauthoritarian, anti-capitalist youth. Who are these young people and what kind of politics is motivating them? For many, the answer is anarchism.

Anarchism is a political philosophy concerned with the freedom of the individual from the power of the state and other forms of authority. Some confusion can arise, however, over the distinction between "left" and "right" versions of anarchism.

"Left" anarchists are not only opposed to state power, but also to private property, inequality and capitalism. "Right" anarchists (e.g. Ayn Rand) also oppose state power, but support an unfettered capitalism and the central role of private ownership.

This paper focuses only on the "left" variety of anarchism, which emerged out of the liberal and socialist movements of the nineteenth century. Anarchism reached its zenith in Spain in the 1930s, collectivizing agriculture 
and industries, before being crushed by totalitarianism. Its influence around the world began to wane with the rising power of the Soviet Union and the increased prosperity of the post-war era.

Despite its overall decline in popularity, however, anarchism experiences short bursts of interest and influence amongst activist intellectuals and young people every decade or so, most dramatically with the rise of the New Left in the 1960s. Interest arose again during the Punk era of the 1970s, then again with the growth of the Internet and "cyberanarchy" in the 1990s, and today with the activities surrounding the anti-globalization, anti-neoliberal, and anti-imperialist struggles.

As a result, librarians can expect user interest in this topic to rise, fall, and rise again, and should therefore be prepared with a well-managed collection of classic and contemporary material.

This guide was written to assist librarians, teachers, students and activists in their anarchist research. The resource lists are by no means comprehensive, but will instead direct researchers toward some of the best materials available in English.

\section{Subject Headings}

In addition to the materials recommended in this bibliography, further information will be found using some of the following subject headings:

Anarchism;

Anarchism - bibliographies;

Anarchism - drama;

Anarchism - encyclopedias;

Anarchism - history;

Anarchism - periodicals;

Anarchism - Spain (or other countries);

Anarchism in art;

Anarchism in literature;

Anarchists;

Bakunin, Mikhail Aleksandrovich, 1814-1876 (or other prominent anarchist personality);

Jewish anarchists; 
Journalism, anarchist;

Press, anarchist; and

Women anarchists.

\section{Selection Tools}

Mainstream selection tools will not review much of the material that would make up a strong anarchist collection. While it is important to continue to make use of resources such as Publishers' Weekly, Choice, the Times Literary Supplement, etc., more specialized tools are available. The following sources would be useful for academic or larger public libraries.

Alternative Press Review, PO Box 4710, Arlington, VA, USA, 22204-4710 http://www.altpr.org/

Original articles, reprinted essays, and reviews ranging from zines to academic journals and books.

Jones, M.J. et al. (1999), Annotations: A Guide to the Independent Critical Press, 2nd ed., Alternative Press Center, Baltimore, MD, USA

A directory of alternative periodicals, complete with detailed annotations, subscription prices, and contact information.

Broken Pencil: The Magazine of Zine Culture and the Independent Arts, PO Box 203, Station P, Toronto, ON, Canada M5S 2 S7

http://www.brokenpencil.com/

Devoted exclusively to underground culture and independent arts, featuring articles, fiction, interviews, zine excerpts, and reviews of books, Web sites, zines, videos, and art. 
Counterpoise: For Social Responsibilities, Liberty and Dissent, 1716 SW Williston Road, Gainesville, FL, USA, 32608-4049

http://www.counterpoise.info/

International journal for the alternative press, including reviews, letters, and essays.

A Reader's Guide to the Underground Press, PO Box 330156, Murfreesboro, TN, USA, 37113-0156

http://www.undergroundpress.org/

A review publication covering small-scale, amateur books and periodicals.

\section{Publishers}

Some of the most highly regarded and prolific publishers of anarchist and anarchist-related information include:

AK Press, 674-A 23rd Street, Oakland, CA, USA 94612

http://www.akpress.org/

Black Rose Books, C.P. 1258, Succ. Place du Parc, Montreal, QC, Canada H2W 2R3

http://www.web.net/blackrosebooks/

Freedom Press, 84b Whitechapel High Street, London, UK E1 7QX

Sharp Press, PO Box 1731, Tucson, AZ, USA 85702

http://www.seesharppress.com/

South End Press, 7 Brookline Street No. 1, Cambridge, MA, USA 02139-4146 http://www.southendpress.org/

\section{Booksellers}

Most anarchist material will not be readily available from mainstream book superstores. Instead, visit local used and alternative book stores. These will be much more likely to stock magazines, newspapers, and pamphlets as well. 
Another source of material is the anarchist book fair. San Francisco held its Eighth Annual Anarchist Bookfair in March 2003 and Montreal's Fourth Anarchist Bookfair (http://www.tao.ca/lombrenoire/indexeng.html) was held in May 2003. The London Anarchist Bookfair (http://freespace. virgin.net/anarchist.bookfair/) has been going since 1983 and gets bigger and better each year, with more material and increasing diversity.

These fairs provide great opportunities to acquire material, but also allow for making connections and meeting interesting people.

\section{Bibliographies}

Some extremely helpful anarchist bibliographies have been written to guide those unfamiliar with the topic toward some of the most important materials:

Bibliography for Anarchist FAQ http://www.infoshop.org/faq/biblio.html An exhaustive (though currently incomplete) source, the bibliography is divided into three sections: anthologies of anarchist authors; books by or about anarchists, libertarians or anarchist movements and history; and books by non-anarchists and libertarians.

\section{A Comprehensive Anarchist Bibliography}

http://dwardmac.pitzer.edu/Anarchist_Archives/unifiedbiblio.html.

Includes a list of significant general works, as well as lists for the major theorists.

Nordquist, J. (1999), Anarchism: Contemporary Theories: A Bibliography, Reference and Research Services, Santa Cruz, CA

The most current bibliography available.

Nursey-Bray, P. (Ed.) (1992), Anarchist Thinkers and Thought: An Annotated Bibliography, Greenwood Press, New York, NY

Includes English language works by and about major theorists, general theoretical and historical writings, international experiences, as well as journal, bibliographies, and theses. 


\section{Reference Works}

There are few reference works specifically on anarchism. Most are more general sources on revolution and revolutionaries, which often carry some useful information on anarchism. However, one source does stand out for its focus on the topic, and makes an excellent starting point for research.

Gay, K. and Gay, M.K. (1999), Encyclopedia of Political Anarchy, ABC-CLIO, Santa Barbara, CA

This covers the people, organizations, events, and ideas comprising political anarchy. Entries provide cross-references and bibliography, including references to Web sites. Includes a comprehensive bibliography and detailed subject index.

Some general reference sources include the following:

Goldstone, J. (1998), The Encyclopedia of Political Revolution, Congressional Quarterly, Washington, DC

Includes scholarly entries on international revolutionary events. Little specific information on anarchism, but still a useful overview.

Hyams, E. (1973), A Dictionary of Modern Revolution, Allen Lane, London A concise introduction to revolutionary events, people and ideas, with several relevant anarchist entries.

van Creveld, M. (1996), Encyclopedia of Revolutions and Revolutionaries: From Anarchism to Zhou Enlai, Facts on File, New York, NY

A source of further background material which includes biographical sketches and historical overviews.

\section{Essential Texts}

The following texts represent some of the central works of these important anarchist writers, are significant anthologies, or provide some of the most comprehensive overviews of the subject. Any of these would be appropriate for academic or larger public libraries. 
Biehl, J. (Ed.) (1999), The Murray Bookchin Reader, Black Rose Books, Montreal An anthology of the works of Murray Bookchin (1921-), well known for his ideas on social ecology, which connect social inequality to ecological degradation.

Capouya, E. and Tompkins, K. (Eds) (1975), The Essential Kropotkin, Liveright, New York, NY

Brings together the principle works of the Russian prince Peter Kropotkin (1842-1921), who gave anarchism a scientific basis through his examination of evolution and human development.

Dolgoff, S. (Ed.) (1980), Bakunin on Anarchy: Selected Works by the Activist founder of World Anarchism, rev. 2nd ed., Black Rose Books, Montreal Sam Dolgoff's compilation the writings of Russian aristocrat Mikhail Bakunin (1814-1876), Marx's greatest rival in the First International.

Goldman, E. (1996), Red Emma Speaks: An Emma Goldman Reader, Prometheus Books, Amherst, MA

Brings together some of the best essays by Emma Goldman (1869-1940), whose organization for peace, unions, and women's rights resulted in her imprisonment, deportation, and label as "the most dangerous woman in America".

Guerin, D. (1970), Anarchism, Monthly Review Press, New York, NY An excellent starting point to anarchist history and ideas. This is also a good choice for secondary school libraries, providing an accessible introduction.

Kramnick, I. (Ed.) (2001), Enquiry Concerning Political Justice and Its Influence on Modern Morals and Happiness, Penguin, London

The principle work of William Godwin (1756-1836), the first anarchist philosopher, describes an ideal society without government.

Marshall, P. (1993), Demanding the Impossible: A History of Anarchism. Harper Collins; Fontana Press, London

A detailed overview of the historical development of anarchist thought and personalities. 
Peck, J. (Ed.) (1987), The Chomsky Reader, Pantheon Books, New York, NY An anthology of Noam Chomsky (1928-), noted linguist, US foreign policy critic, and media analyst, described by The New York Times as the most important intellectual alive today. Also recommended for secondary school libraries.

Tucker, B.R. (Ed.) (1902), What Is Property?: An Inquiry into the Principle of Right and Government, Best Books, Temecula, CA

One of the most important works by the influential French anarchist PierreJoseph Proudhon (1809-1865), to which he answers, "Theft"!

Woodcock, G. (1987), Anarchism: A History of Libertarian Ideas and Movements, Penguin, Toronto

A classic introductory text by George Woodcock (1912-1995), one of anarchism's most prolific modern intellectuals.

\section{International Texts}

Internationalism is a fundamental component of anarchist thought and action. The following books provide insight into how anarchism developed in different countries.

\section{China}

Dirlik, A. (1991), Anarchism in the Chinese Revolution, University of California Press, Berkeley, CA.

Scalapino, R.A. and Yu, G.T. (1980), The Chinese Anarchist Movement, Greenwood Press, Westport, CT. 


\section{Cuba}

Dolgoff, S. (1976), The Cuban Revolution: A Critical Perspective, Black Rose Books, Montreal.

Fernandez, F. (2001), Cuban Anarchism: The History of a Movement, Sharp Press, Tucson, AZ.

\section{Mexico}

Hart, J.M. (1987), Anarchism and the Mexican Working Class, 1860-1931, University of Texas Press, Austin, TX.

Hodges, D.C. (1995), Mexican Anarchism after the Revolution, University of Texas Press, Austin, TX.

MacLachlan, C.M. (1991), Anarchism and the Mexican Revolution: The Political Trials of Ricardo Flores Magon in the United States, University of California Press, Berkeley, CA.

\section{Russia}

Avrich, P. (1971), The Russian Anarchists, W.W. Norton, New York, NY.

Avrich, P. (1973), The Anarchists in the Russian Revolution, Cornell University Press, Ithaca, NY.

\section{Spain}

Ackelsberg, M.A. (1991), Free Women of Spain: Anarchism and the Struggle for the Emancipation of Women, Indiana University Press, Bloomington, IL. 
Bookchin, M. (1998), Spanish Anarchists: The Heroic Years 1868-1936, AK Press, Edinburgh.

Dolgoff, S. (1974), The Anarchist Collectives: Workers Self-management in Spain, 1936-1939, Black Rose Books, Montreal.

\section{USA}

Avrich, P. (1986), The Haymarket Tragedy, Princeton University Press, Princeton, NJ.

Avrich, P. (1996), Anarchist Voices: An Oral History of Anarchism in America, Princeton University Press, Princeton, NJ.

\section{Recent Publications}

Anarchist ideas are still of interest to writers, who continue to explore its theories and practices. Some recent publications include the following.

Call, L. (2003), Postmodern Anarchism, Lexington Books, Lanham, MD Draws together postmodernism's critique of contemporary power structures and the radical anti-authoritarianism of classical anarchism and argues for a new form of anti-capitalist activism for the twenty-first century. A bibliography of selected multimedia anarchist resources

Ferrell, J. (2001), Tearing down the Streets: Adventures in Urban Anarchy, Palgrave Publishers, New York, NY

Examines the cultural and political struggles of young people, graffiti artists, buskers, skaterboarders, militant bicyclists, the homeless, and others over urban public space.

Glassgold, P. (2001), Anarchy!! An Anthology of Emma Goldman's Mother Earth, Counterpoint Press, Washington, DC 
Selections from the magazine founded by Emma Goldman, with articles on social, political, cultural, and historical issues from an anarchist perspective from 1906 to 1917.

Ludlow, P. (2001), Crypto Anarchy, Cyberstates, and Pirate Utopias, MIT, London

Examines emerging structures of authority within online communities and the possibilities for alternatives.

Roussopoulos, D. (Ed.) (2002), The Anarchist Papers, rev. ed., Black Rose Books, Montreal

Contains essays by a variety of the most well known anarchist writers, including Bookchin, Chomsky, and Woodcock. Topics include green politics, libertarian municipalism, feminism, conformity, and more.

Quiet Rumours: An Anarcha-feminist Reader (2003), AK Press, Edinburgh Classic and contemporary essays, interviews and pamphlets exploring the relationship between anarchism and feminism.

Skirda, A. (2002), Facing the Enemy: A History of Anarchist Organization from Proudhon to May 1968, AK Press, Edinburgh

Traces the history of anarchism as a political movement and ideology across the nineteenth and twentieth centuries.

\section{Journals}

The majority of anarchist journals are produced in the spirit of "do it yourself" (DIY), making them locally focused and largely invisible to indexes. There are some, however, that have a wider distribution and exposure.

Anarchist Studies, 99a Wallis Road, London, E9 5LN

A scholarly, interdisciplinary journal, examining anarchist culture, philosophy, and political action.

Also covers the application of anarchist ideas to scholarly research. 
Anarcho-syndicalist Review, PO Box 2824, Champaign, IL, USA, 61825.

http://www.syndicalist.org/

Peer-reviewed source of anarchist book reviews.

Anarchy: A Journal of Desire Armed, CAL Press, PO Box 1446, Columbia, MO, USA, 65205-1446.

http://www.anarchymag.org/

One of the longest running anarchist publications, written from a variety of anarchist perspectives.

The Raven: Anarchist Quarterly, Freedom Press, 84b Whitechapel High Street, London, E1 7QX

Another scholarly anarchist journal, with each issue devoted to a different topic (education, communications, sociology, religion, etc.).

Social Anarchism: A Magazine of Current Anarchist Writing, 2743 Maryland Ave, Baltimore, MD, USA, 21218.

http://www.socialanarchism.org/

Includes current debates within the anarchist community, with contributions by central figures such as Chomsky and Bookchin, as well as many reviews. Peer-reviewed.

Z Magazine, 18 Millfield Street, Woods Hole, MA, USA, 02543. http://www.zmag.org/ZMagSite/curTOC.htm

Although not limited to anarchist thought, this long-running, popular newstype magazine features articles from some of the most respected antiauthoritarian and alternative writers in the world today. Although most of the periodicals on this list are primarily of academic interest, Z Magazine makes a useful addition to public library collections, with a news magazine format and more accessible style.

\section{Indexes}

Some of the most significant anarchist literature is published in a variety of small periodicals. It would be important for any serious anarchist collection to not only subscribe to many of these publications, but also to the indexes 
that would help readers find exactly what they are looking for. Some indexes with anarchist or anti-authoritarian coverage include:

\section{Alternative Press Index}

This covers about 250 alternative, radical and leftist publications from North America. The print index dates back to 1969 and the online index goes back to 1991. All of the journals listed above are indexed here.

\section{The Left Index}

A quarterly index to approximately 80 journals that have a "radical or left perspective." Articles are indexed only if they contain lengthy, critical or analytical material. Topics span a broad range of humanities, social sciences and science subjects. Has an extensive book review section.

Although the previous two indexes would be the best sources for anarchist information, the traditional scholarly indexes below are also of some value:

International Political Science Abstracts

Print coverage dates back to 1951, online back to 1989.

Sociological Abstracts

Coverage in print dates back to 1953, online back to 1963.

\section{Humanities and Social Sciences Index}

One of the most important indexes for scholarly humanities and social science information. Coverage in print goes back to 1907, online back to 1983.

\section{Other Formats}

Library collections must include formats beyond books and periodicals, and important additions to an anarchist collection would include Web sites, ebooks, pamphlets, music, and videos. 


\section{Web Sites}

The Web is an incredible research source for those interested in anarchism, having become the DIY pamphlet of the modern era. By starting with more scholarly sites, and branching out from their recommended links, one uncovers a wealth of information.

Anarchist Archive

http://dwardmac.pitzer.edu/Anarchist_Archives/

An archive of the collected full-text works of major anarchists and an online history of anarchists and anarchist movements world-wide.

The Emma Goldman Papers

http://sunsite.berkeley.edu/goldman/

A wonderful multimedia resource, with primarydocuments, images, video, secondary school curriculum resources, and more.

Flag.blackened.net

http://flag.blackened.net/

One of the best anarchist sites online. Provides overviews and background to the subject, as well as news, discussions, zines, and links.

Infoshop

http://infoshop.org/

A huge collection of links and articles about anarchism. Good source of upcoming events, such as conferences and bookfairs. Features the Anarchist Librarians Web, the online magazine, Practical Anarchy, and the Internet Anarchist University.

Institute for Anarchist Studies

http://www.anarchist-studies.org/

Scholarly anarchist site. Provides a recommended reading list. 
The Kate Sharpley Library

http://www.katesharpleylibrary.net/

Dedicated to researching and restoring the history of the anarchist movement and regularly publishes information on lost areas of anarchist history.

Contains an extensive Yiddish anarchist bibliography.

The Spunk Library

http://www.spunk.org/

Another useful online library of full-text anarchist documents. Includes a title and subject catalogue.

ZNet

http://www.zmag.org/

Features a huge, continuously updated library of full-text articles from anarchists and antineoliberals such as Noam Chomsky and Naomi Klein on daily issues. Includes online tutorials, videos, Z Magazine online, and an "Anarchy Watch" section.

\section{Music}

From the labour songs of the IWW to the antiauthoritarian themes of contemporary political bands, music has always been an important part of the anarchist tradition and the "festival of the oppressed".

Anarchist and Radical Music and Art

http://www.spunk.org/texts/intro/faq/sp001547/links.html\#music

Provides links to a variety of anarchist and radical musicians.

Anarchist, Libertarian and Rebel Songs

http://anarchism.ws/songs.html

Includes lyrics of rebel songs from around the world.

The Clash (2000), London Calling, Sony

Considered one of the best rock albums of all time by Rolling Stone magazine, it established The Clash's presence outside of the UK. Originally recorded in 1979. 
Chumbawamba (1993), Anarchy. One Little Indian

More pop than punk, this album still contains strong social and political themes. Includes the hit single Enough is Enough.

Rage against the Machine (2000), Renegades, Sony Combines elements of hip hop and heavy metal, with powerful political messages.

Rebel Voices: Songs of the Industrial Workers of the World (1993), Flying Fish A collection of songs from the Wobblies' "Little Red Songbooks".

The Sex Pistols (1990), Never Mind the Bollocks, Here's the Sex Pistols, Warner Brothers

The album that introduced The Sex Pistols to the world. A seminal work not just for the Punk genre, but for music overall. Includes the tracks, Anarchy in the UK and the heavily banned God Save the Queen. Originally recorded in 1977.

\section{E-books}

A growing medium, anarchist e-books titles are increasingly becoming available both on the open Web and in subscription databases.

\section{Anarchist Archives}

http://dwardmac.pitzer.edu/Anarchist_Archives/

An incredible source of copyright-free anarchist electronic text from all of the major theorists. Most of the classics can be found reproduced here in their entirety.

Additional sources of electronic books are Netlibrary (http://www.netlibrary .com/), and Project Gutenberg (http://gutenberg.net/), which each include a small selection of anarchist titles. 


\section{Videos}

Few resources are available for anarchist videos, but most of the following should be relatively easy to obtain.

Emma Goldman, The Anarchist Guest (2000), Romalis Productions, directed by Coleman Romalis Depicts Emma Goldman's tumultuous life from Russia to the USA and her eventual deportation to Canada, where she found exile.

Manufacturing Consent: Noam Chomsky and the Media (1992), Necessary Illusions, directed by Mark Achbar and Peter Wintonick Explores Chomsky's life and ideas, highlighting his analysis of media and ideological control in democratic societies.

District 25(1992), National Film Board of Canada, directed by Robert Craig Follows the 1990 campaign of anarchist book publisher Dimitri Roussopoulos for "Ecology Montreal", Canada's first municipal Green party.

This Is What Democracy Looks Like (2000), Big Noise Films, directed by Jill Freidberg and Rick Rowley

Shot by media activists during the 1999 World Trade Organization protests in Seattle. This video is popular at fundraisers for activist organizations, so careful attention to public performance rights is an issue.

Land and Freedom (1995), Parallax Pictures, directed by Ken Loach A young man from Liverpool travels to Spain to fight fascism. Hospitalized in Barcelona, his political commitment to communism is challenged.

A Place Called Chiapas (1998), National Film Board of Canada, directed by Nettie Wild Explores post-NAFTA Mexico and the "postmodern" Zapatista revolution. 


\section{Ephemera}

Another important source of anarchist information is the wealth of material that can be found in locally produced, DIY posters and pamphlets. These have no distribution source other than the active "leg-work" of the librarian or researcher and his or her contacts in the community. Visits to alternative bookstores, cafes, theatres, and other gathering places can provide a steady supply of such material, which lies at the heart of any anarchist community.

Such ephemera provide a rare insight into the day-to-day activism and politics of local anarchists and allows for the development of a valuable historical record of a lesser known side to many communities. Academic, research, and larger public libraries may be interested in not only collecting posters and pamphlets, but also indexing and possibly digitizing some of it, making it available to an even wider audience.

\section{Censorship Note}

An important issue librarians should be aware of regarding this topic is censorship. Anarchism has challenged power and the powerful for generations, by methods both legal and illegal, and has been attacked both as a movement and as an idea. As a result, libraries should be prepared for challenges to any anarchist materials in their collection, whether in print or online (the strong popular connection between anarchism and terrorism makes this more important today than it has been for many years).

One title that is often included on censorship lists is Powell's (2001) The Anarchist Cookbook, a terrorist manual that provides different "recipes" for home made explosives, instructions for demolishing bridges, etc. This book is quite controversial, and most anarchists renounce it as having little to do with their philosophy at all. Poorly written, it is also very dangerous, as many of the "recipes" could potentially kill the "cook". It has, however, been recently re-printed and is available from Amazon.com and other distributors. Despite the censorship interest, this is not an essential work to include in an anarchist collection. It is of low quality and is only incidentally related to the subject.

Another intellectual freedom issue for anarchist materials relates to the rise of Internet filtering, as many of the filtering programs include "anarchism" and "anarchy" in their exclusion lists. This would make accessing 
the wealth of anarchist material online impossible. It is important that researchers and librarians are aware of this issue, so that low search results are not mistakenly interpreted as a lack of information on this topic.

Finally, librarians in some countries may also wish to make their users aware that government authorities could potentially be tracking any Internet use, searching for behavior that might be interpreted as subversive or terrorist.

\section{Conclusion}

Any developing anarchist collection would strongly benefit from having a solid core of classic texts combined with an infusion of new materials and non-book formats. Libraries could present a selection of these materials in a public display to show them off to the community, perhaps to coincide with May Day or the next antiglobalization protest.

\section{Further Reading}

Epstein, B. (2001), "Anarchism and the anti-globalization movement", Monthly Review, Vol. 53 No. 4, pp. 1-14.

Graeber, D. (2002), "The new anarchists", New Left Review, Vol. 13, pp. 61-73. 